\title{
Winter Penetration by Mammals of Different Habitats in the Biebrza Valley
}

\author{
Stanisław FEDYK, Zofia GĘBCZYNSSKA, Michalina PUCEK, \\ Jan RACZYNSSKI \& Michał D. SIKORSKI
}

\begin{abstract}
Fedyk S., Gębczyńska Z., Pucek M., Raczyński J. \& Sikorski M. D., 1984: Winter penetration by mammals of different habitats in the Biebrza valley. Acta theriol., 29, 27: 317-336 [With 1 Table \& 5 Figs.]

Tracks left in the snow by wild carnivores, ungulates, rodents and lagomorphs (total of 13 species) were counted over the period of 4 consecutive winters $1977-1980$, over a total distance of $383 \mathrm{~km}$ on a route running through a group of habitats in a peaty river valley (NE Poland). Predators penetrate bog forests, dense undergrowth and the banks of rivers most intensively. Tracks of Cervidae, mainly moose Alces alces (Linnaeus, 1758), were encountered most often in bog willow-birch shrubs, pine forests with rich undergrowth and mixed forests. The greatest variety of species and intensity of penetration are found in mesotrophic bog pine forests, willow - birch trees and bushes, and other deciduous and mixed forests. The extensive open sedge community area exhibited the lowest indices of penetration for the majority of species. Movements of moose in the Biebrza valley depend on the food supply available in winter and vary in different parts of the valley depending on the topographical relationships of boggy habitats and pine stands.

[Mammals Res. Inst., Polish Acad. Sci., 17-230 Białowieża, Poland]
\end{abstract}

\section{INTRODUCTION}

Recording tracks left by animals in the snow has long since been used in ecological studies for a variety of purposes. Because of the needs of game management in the northern regions, attention has been mainly concentrated on the techniques for counting tracks for estimating numbers and density of the animal population (e.g. Formozov, 1932; Nasimovič, 1963; Dzięciołowski, 1976; Kuzjakin, 1979). These methods were also employed to study migrations and certain forms of the animals' activities (feeding, searching for prey, sheltering, and reproductive activity- e.g. Fuller \& Robinson, 1982; Mech, 1966), and also fluctuation of numbers over a cycle of several years (Pulliainen, 1981). Recently increasingly greater use has been made of material collected by this method to estimate winter preferences and the degree to which habitats are utilized by predatory and larger herbivorous mammals (Erlinge, 1977; Fuller \& Robinson, 1982), and also to chart penetration intensity by the isorithmic method (Goszczyński, 1981). 
The purpose of the present studies was to define the degree to which different habitats are used by mammals. On this basis an attempt was made at evaluating the role of the group of bog habitats for mammals occupying the natural river valley. Winter tracking at the same time made it possible to supplement the list of mammal species living there, by animals not so far revealed by the method of standard captures (Raczyński et al., 1983; Raczyński et al., in print).

\section{STUDY AREA}

The glacial Biebrza valley (the valley formed by the glacial outwash in the area which is now Biebrza river) is situated in NE Poland and is divided into three basins (Fig. 1). The studies were carried out in the group of habitats forming the bog physiocenosis of the Biebrza river valley. This area, 300,000 ha in extent, is characterized by the occurrence over a very large area of a group of low peat bogs in which there is a continuous (over the greater part of the area)) peat-forming process (Pałczyński, 1975). The distribution of habitats forms the expression of ecological zoning both across and along the valley (Okruszko, 1973; Oświt, 1973), while anthropogenic influences are limited contemporarily to extensive use of sedge communities as permanent grasslands and do not bring about any fundamental transformation of the vegetation cover (Pałczyński, 1981).

The group of habitats in the Biebrza valley forms a compact system of biotopes of well-known origin (Oświt \& Zurek, 1981). Since the final glacial period peat-forming processes have dominated there, controlled by hydrological and climatic conditions. The anthropogenic phase did not basically disturb the structure of habitats or the ecological processes of this physiocenosis. This situation justifies our treating the occupation and use of the valley by animals as a phenomenon to a great degree natural and ecologically conditioned.

Hydrological conditions determine the boundaries of the different plant associations. The extensive area of the valley is occupied by sedge and sedge-moss communities (cf. Table 1, No. 1), bounded along the beds of rivers and old water courses by rushes (Phalidetum arundinaceae association) and reed beds (ScirpoPhragmitetum) (Table 1, No. 16). Bog willow-birch shrubs and the early phases of ligneous plants are spreading over considerable areas of the unmown sedge communities. These are usually communities of the Salix cinerea - Betula pubescens type (No. 2). Within the area of the peaty valley mineral elevations known as "hummocks" occur in places, which, depending on the fertility of the biotope and elevation above the level of the peat bed, are covered with grass (No. 6) or with shrubs and tree stands of the Tilio-Carpinetum type (No. 5). In the zone where ground water wells up, alder woods (Carici-elongatae-Alnetum) grow along the mineral edges of the valley. Similar associations of bog deciduous forests are formed by two large areas of bog birch forests - Betuletum pubescentis-verrucosae. Both types of habitats have been combined in the present paper into a joint alder group (No. 7). Oak-hornbeam forests of the Tilio-Carpinetum type (No. 9) occur in the valley over small areas in the form of separate islands of trees. The more fertile mineral soils in the glacial river valley are occupied by mixed forests (No. 10), while the majority of the whole area consists of dry pine 

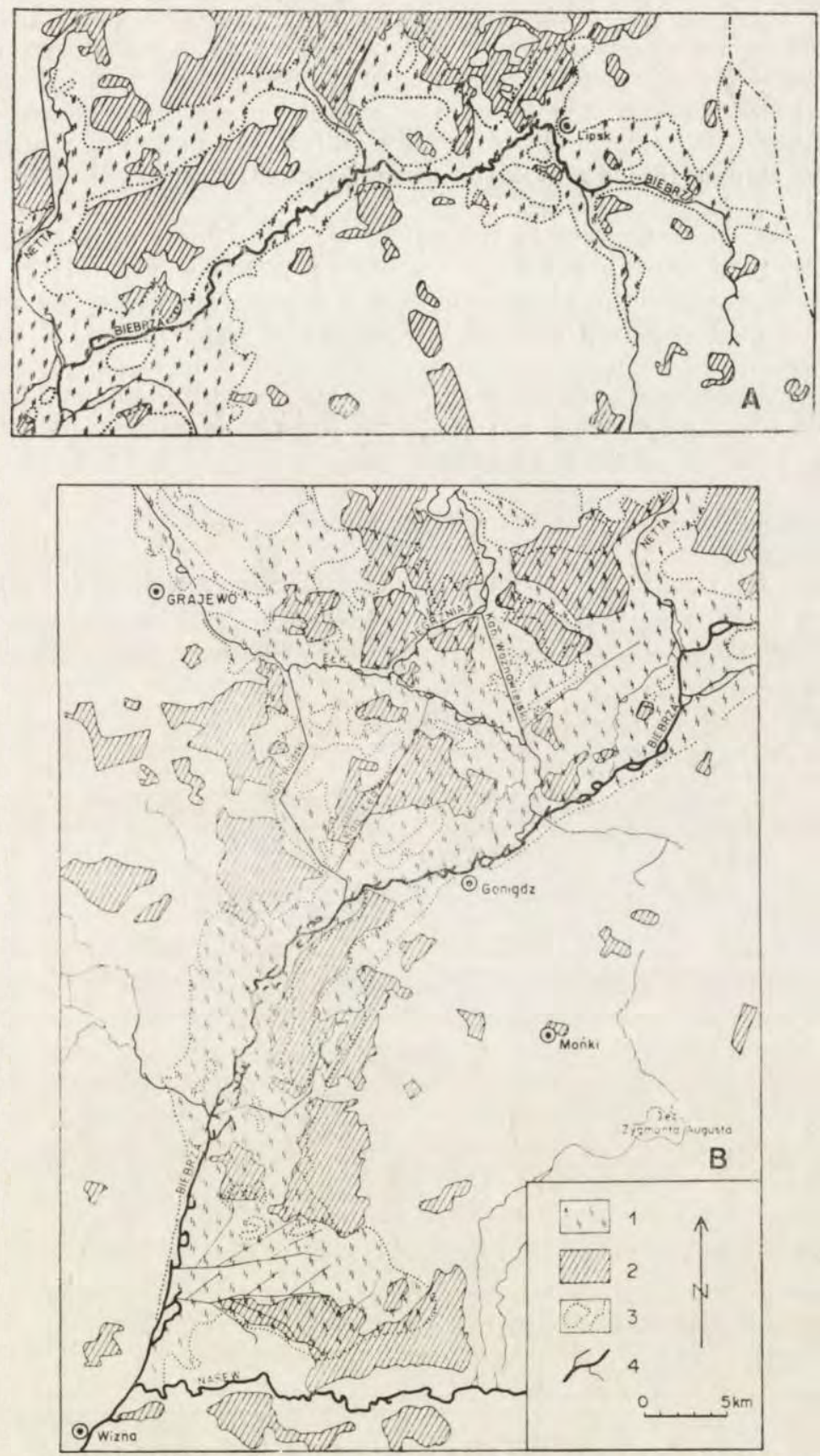

Fig. 1. Map of the Biebrza valley.

A - upper basin, B - middle and lower basin, 1 - open sedge communities, 2 - forests, 3 - hummocks and boundaries of mineral soils, 4 - stream system. 
forests, (No. 13), or wet pine forests with rich undergrowth (No. 12, 14) of the Dicrano-Pinion alliance. Tracking was also carried out in bog pine forests of the Vaccinio-uliginosi-Pinetum type (No. 11), the greater part of data being obtained from the mesotrophic variant of this association: Vaccinio-uliginosiPinetum, subass. salicetosum cinereae. The tracking routes also ran through ecotone zones (No. 8) and through parts of meadows and fields adjacent to the river valley (No. 15).

The snow cover persists in the valley for an average of 104 days a year (Krzywonos, 1965). During the study period, the $1978 / 79$ winter was distinguished by an exceptionally deep snow cover about $80-100 \mathrm{~cm}$ which lay for a long time, which most certainly affected the activity of some species of animals (cf. section 5).

An important factor affecting the habitats in which animals live in the valley is the autumn flooding of rivers, which results is sedge communities being covered by water or ice throughout the winter.

\section{METHODS}

In February tracks were counted during 4 successive winters from 1977-1980, in all three basins of the glacial river valley, while the snow cover persisted. Tracking routes (usually different) - were arranged so that they intersected

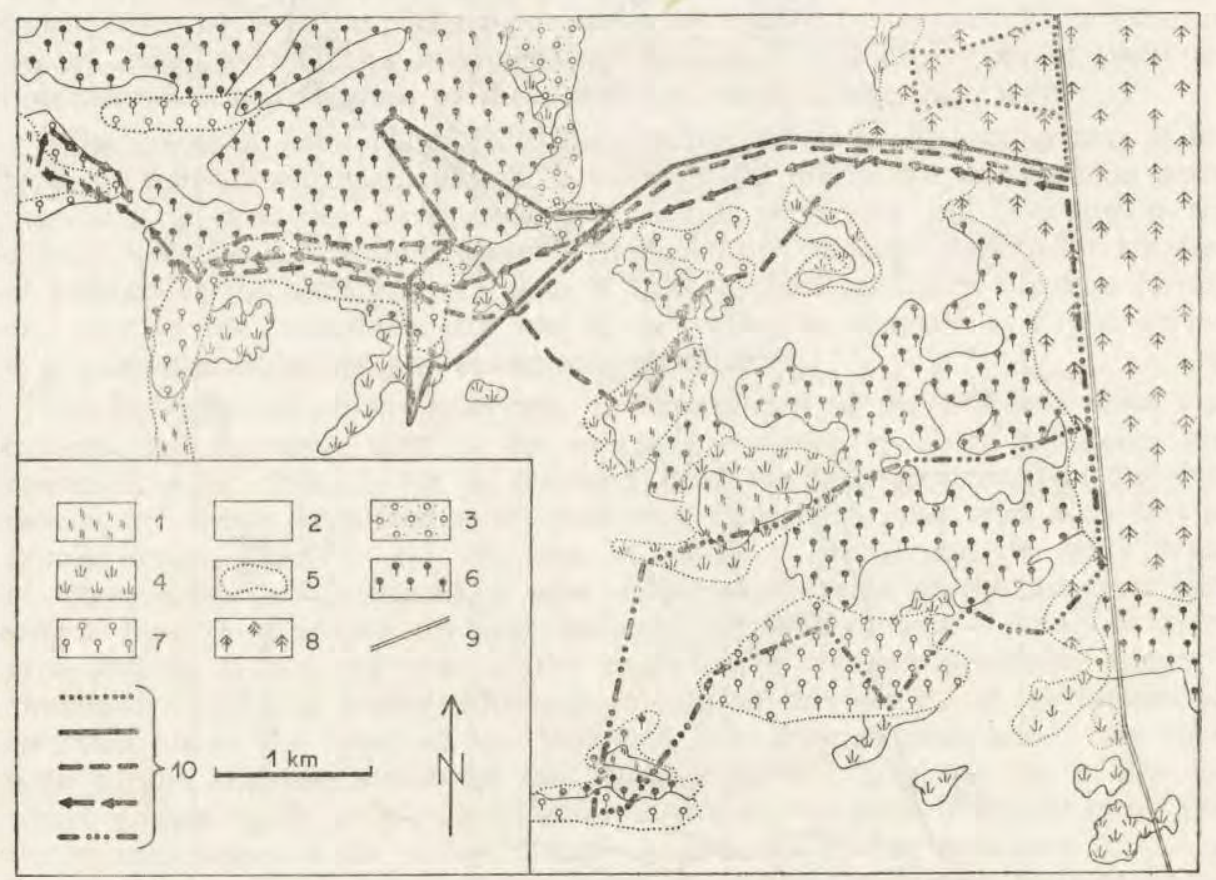

Fig. 2. Section of the area showing the observation routes.

1 - meadows, 2 - open sedge communities, 3 - sedge communities with shrubs $<10$ years old, $4-$ bog willow-birch shrubs $>10$ years old, $5-$ hummocks and boundaries of mineral soils, 6 - bog alder forests, 7 - oak-hornbeam forests, 8 - dry pine forests, 9 - roads, 10 - tracking routes. 


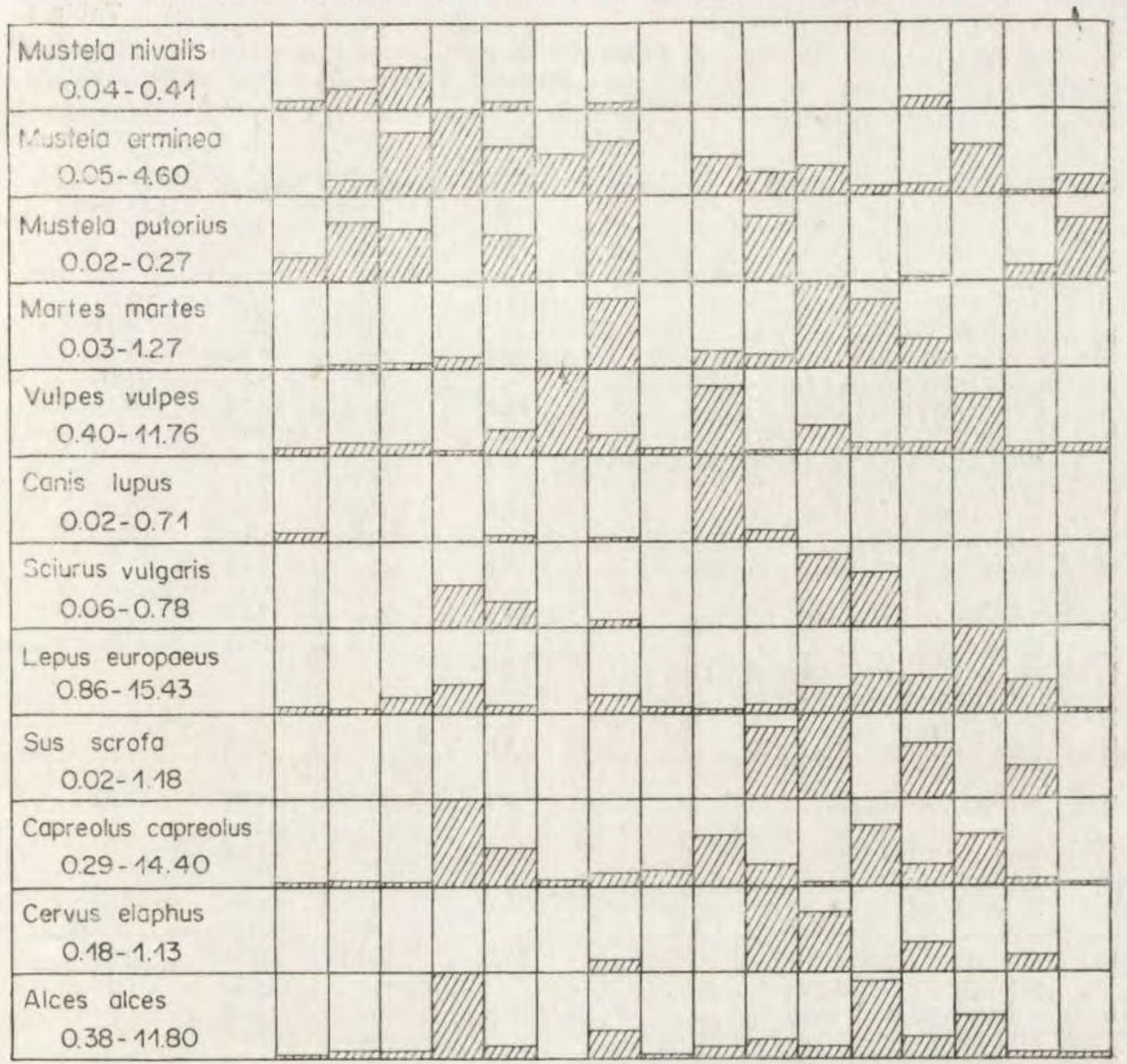

\section{\begin{tabular}{l|l|l|l|l|l|l|l|l|l|l|l|l|l|l|l|l|l|l|l|l|l|l|l|l|l|l|l|l|l|l|l|l|l|} 
Habitats & 1 & 2 & 3 & 4 & 5 & 6 & 7 & 8 & 9 & 10 & 11 & 12 & 13 & 14 & 15 & 16 \\
\hline
\end{tabular}}

Fig. 3. Comparison of intensity of penetration by mammals in different habitats. Columns illustrate differences in percentage of penetration by different species. The maximum penetration index $(A)$ for each species (from left column) was taken separately as $100 \%$ (cf. text p. 324).

1 - open sedge communities, 2 - sedge communities with shrubs $<10$ years old, 3 - dense willow thickest, 4 - bog willow-birch shrubs and stands, 5 - hummocks with shrubs and tree stands, 6 - meadow parts of hummocks, 7 - bog alder forests and bog birch forests (including clear-cuts), 8 - boundary zones between alder forests and sedge communities, 9 - oak-hornbeam forests, $10-$ mixed forests, 11 - bog pine forests (mainly mesotrophic variant), 12 - pine forests with rich undergrowth, 13 - dry pine forests (old stands and plantations $>10$ years old, $14-$ clear-cuts and pine plantations $<10$ years old, $15-$ meadows and fields, $16-$ banks of the rivers and streams. 
Table 1

Comparison of penetration indices (A) for 13 species Number of recorded tracks on observation

\begin{tabular}{|c|c|c|c|c|c|}
\hline No. & Habitat & $\begin{array}{c}\text { Total } \\
\text { routes } \\
\text { lenght } \\
\mathrm{km}\end{array}$ & Weasel & Stoat & $\begin{array}{c}\text { Common } \\
\text { polecat }\end{array}$ \\
\hline 1 & $\begin{array}{l}\text { Open sedge } \\
\text { communities }\end{array}$ & 75.6 & $\begin{array}{l}0.05 \\
(4)\end{array}$ & $\begin{array}{l}0.29 \\
(22)\end{array}$ & $\begin{array}{l}0.08 \\
(6)\end{array}$ \\
\hline 2 & $\begin{array}{l}\text { Sedge communities } \\
\text { with shrubs }<10 \text { years old }\end{array}$ & 62.1 & $\begin{array}{l}0.11 \\
(7)\end{array}$ & $\begin{array}{l}0.85 \\
(53)\end{array}$ & $\begin{array}{l}0.19 \\
(12)\end{array}$ \\
\hline 3 & Dense willow thickets & 23.9 & $\begin{array}{l}0.21 \\
(5)\end{array}$ & $\begin{array}{l}3.35 \\
(80)\end{array}$ & $\begin{array}{l}0.17 \\
(4)\end{array}$ \\
\hline 4 & Bog willow-birch shrubs and stands & 5.0 & & $\begin{array}{l}4.60 \\
(23)\end{array}$ & \\
\hline 5 & $\begin{array}{l}\text { Hummocks with shrubs } \\
\text { and tree stands }\end{array}$ & 20.1 & $\begin{array}{l}0.05 \\
(1)\end{array}$ & $\begin{array}{l}2.84 \\
(57)\end{array}$ & $\begin{array}{l}0.15 \\
(3)\end{array}$ \\
\hline 6 & Meadow parts of hummocks & 0.8 & & $\begin{array}{l}2.35 \\
(2)\end{array}$ & \\
\hline 7 & Bog alder and birch forests & 48.5 & $\begin{array}{l}0.04 \\
(2)\end{array}$ & $\begin{array}{r}2.93 \\
(142)\end{array}$ & $\begin{array}{l}0.27 \\
(13)\end{array}$ \\
\hline 8 & $\begin{array}{l}\text { Boundary zones between alder } \\
\text { forests and sedge communities }\end{array}$ & 1.8 & & & \\
\hline 9 & Oak-hornbeam forests & 7.0 & & $\begin{array}{l}2.00 \\
(14)\end{array}$ & \\
\hline 10 & Mixed forests & 9.7 & & $\begin{array}{l}1.34 \\
(13)\end{array}$ & $\begin{array}{l}0.21 \\
(2)\end{array}$ \\
\hline 11 & $\begin{array}{l}\text { Bog pine forests - } \\
\text { typical and mestrophic }\end{array}$ & 22.9 & & $\begin{array}{l}1.62 \\
(37)\end{array}$ & \\
\hline 12 & Pine forests with rich undergrowth & 6.0 & & $\begin{array}{l}0.17 \\
(1)\end{array}$ & \\
\hline 13 & $\begin{array}{l}\text { Dry pine forests incl. } \\
\text { plantations }>10 \text { years old }\end{array}$ & 55.2 & $\begin{array}{l}0.07 \\
(4)\end{array}$ & $\begin{array}{l}0.24 \\
(13)\end{array}$ & $\begin{array}{l}0.02 \\
(1)\end{array}$ \\
\hline 14 & $\begin{array}{l}\text { Clear-cuts and pine } \\
\text { plantations }<10 \text { years old }\end{array}$ & 1.8 & & $\begin{array}{l}2.86 \\
(5)\end{array}$ & \\
\hline 15 & Meadows and fields & 18.5 & & $\begin{array}{l}0.05 \\
(1)\end{array}$ & $\begin{array}{l}0.05 \\
(1)\end{array}$ \\
\hline \multirow[t]{2}{*}{16} & Banks of the rivers and streams & 24.4 & $\begin{array}{l}0.41 \\
(10)\end{array}$ & $\begin{array}{l}0.90 \\
(22)\end{array}$ & $\begin{array}{l}0.20 \\
(5)\end{array}$ \\
\hline & $\begin{array}{l}\text { Average indices } A \\
\text { Total }\end{array}$ & 383.3 & $\begin{array}{l}0.09 \\
(33)\end{array}$ & $\begin{array}{r}1.26 \\
(485)\end{array}$ & $\begin{array}{c}0.12 \\
(47)\end{array}$ \\
\hline
\end{tabular}


of mammals in different types of habitats.

routes $(n t)$ are given in brackets.

\begin{tabular}{|c|c|c|c|c|c|c|c|c|c|}
\hline $\begin{array}{l}\text { Pine } \\
\text { marten }\end{array}$ & $\begin{array}{r}\text { Red } \\
\text { fox }\end{array}$ & $\begin{array}{c}\text { Raccoon } \\
\text { dog }\end{array}$ & Wolf & $\begin{array}{c}\text { Red } \\
\text { squirrel }\end{array}$ & $\begin{array}{c}\text { Brown } \\
\text { hare }\end{array}$ & $\begin{array}{l}\text { Wild } \\
\text { boar }\end{array}$ & $\begin{array}{l}\text { Roe } \\
\text { deer }\end{array}$ & $\begin{array}{l}\text { Red } \\
\text { deer }\end{array}$ & Moose \\
\hline & 1.34 & 0.08 & 0.09 & \multirow{10}{*}{$\begin{array}{l}0.40 \\
(2) \\
0.25 \\
(5)\end{array}$} & 1.47 & \multirow{10}{*}{$\begin{array}{l}0.02 \\
(1)\end{array}$} & 0.37 & & 0.38 \\
\hline & (101) & (6) & (7) & & (111) & & (28) & & (29) \\
\hline 0.03 & 1.82 & 0.02 & & & 1.06 & & 1.16 & & 1.08 \\
\hline (2) & (113) & (1) & & & (66) & & (72) & & (67) \\
\hline 0.08 & 1.76 & 0.04 & & & 3.39 & & 0.88 & & 1.21 \\
\hline (2) & (42) & (1) & & & (81) & & (21) & & (29) \\
\hline \multirow{4}{*}{$\begin{array}{l}0.20 \\
\text { (1) }\end{array}$} & 0.40 & & & & 5.20 & & 14.40 & & 11.80 \\
\hline & (2) & & \multirow{3}{*}{$\begin{array}{l}0.05 \\
(1)\end{array}$} & & (26) & & (72) & & (59) \\
\hline & 3.68 & & & & 1.39 & & 6.37 & & $\begin{array}{l}1.69 \\
(34)\end{array}$ \\
\hline & $\begin{array}{c}(74) \\
11.76 \\
(10)\end{array}$ & & & & (28) & & $\begin{array}{l}(128) \\
1.18 \\
\text { (1) }\end{array}$ & & \\
\hline 1.05 & 2.88 & & 0.02 & 0.06 & 3.47 & & 2.56 & 0.18 & 3.92 \\
\hline (51) & (139) & & (1) & (3) & (168) & & (124) & (9) & (190) \\
\hline & 1.11 & & & & 1.11 & & 2.78 & & 0.56 \\
\hline & 9.34 & & 0.71 & & $\begin{array}{l}(2) \\
0.86\end{array}$ & & $\begin{array}{l}\text { (5) } \\
871\end{array}$ & & $\begin{array}{l}\text { (1) } \\
1.57\end{array}$ \\
\hline $\begin{array}{l}0.20 \\
(2)\end{array}$ & (66) & & (5) & & (6) & & (61) & & (11) \\
\hline 0.21 & 0.72 & & 0.10 & & 1.35 & 1.03 & 3.40 & 1.13 & 2.68 \\
\hline (2) & (7) & & (1) & & (15) & (10) & (33) & (11) & (26) \\
\hline 1.27 & 4.10 & 0.04 & & 0.66 & 5.02 & 1.18 & 0.96 & 0.79 & 1.62 \\
\hline (29) & (94) & (1) & & (15) & (115) & (27) & (22) & (18) & (37) \\
\hline 1.00 & 1.67 & & & 0.50 & 6.67 & & 10.33 & & 10.33 \\
\hline (6) & (10) & & & (3) & $(40)$ & & (62) & & (62) \\
\hline $\begin{array}{l}0.45 \\
(25)\end{array}$ & $\begin{array}{l}1.65 \\
(91)\end{array}$ & & & $\begin{array}{c}0.78 \\
(43)\end{array}$ & $\begin{array}{r}6.70 \\
(370)\end{array}$ & $\begin{array}{l}0.80 \\
(44)\end{array}$ & $\begin{array}{r}3.51 \\
(194)\end{array}$ & 0.40 & $\begin{array}{r}3.13 \\
(173)\end{array}$ \\
\hline & 8.00 & & & & 15.43 & & $\begin{array}{l}8.57 \\
\text { (15) }\end{array}$ & & $\begin{array}{l}5.71 \\
(10)\end{array}$ \\
\hline & & & & & 6.47 & 0.48 & 1.18 & 0.22 & 0.92 \\
\hline & $\begin{array}{l}1.18 \\
(22)\end{array}$ & & & & (120) & (9) & (22) & (4) & (17) \\
\hline & $\begin{array}{l}1.64 \\
(40)\end{array}$ & & & & $\begin{array}{l}0.98 \\
(24)\end{array}$ & & $\begin{array}{l}0.29 \\
(7)\end{array}$ & & $\begin{array}{l}1.02 \\
(25)\end{array}$ \\
\hline $\begin{array}{r}0.31 \\
(120)\end{array}$ & $\begin{array}{r}2.16 \\
(827)\end{array}$ & $\begin{array}{l}0.02 \\
(9)\end{array}$ & $\begin{array}{c}0.04 \\
(15)\end{array}$ & $\begin{array}{c}0.18 \\
(71)\end{array}$ & $\begin{array}{c}3.13 \\
(1196)\end{array}$ & $\begin{array}{l}0.24 \\
(91)\end{array}$ & $\begin{array}{r}2.26 \\
(867)\end{array}$ & $\begin{array}{c}0.17 \\
(64)\end{array}$ & $\begin{array}{r}2.01 \\
(770)\end{array}$ \\
\hline
\end{tabular}


different habitats in the valley, usually transversely to their zonal distribution (Fig. 2). The observers travelled on skis, recording the number of all tracks of mammals possible to identify, which crossed the route. Counting was thus made of tracks from different periods, depending on the time the fresh layer of snow persisted. The routes were entered on a map with scale $1: 25000$, on the basis of topographical sites, and from this calculation was made of the length of sections of the route in different habitats. Care was taken to see that the length of routes in the main habitats (Table 1) corresponded approximately to the proportions of these habitats in the valley. Total length of all routes was over $380 \mathrm{~km}$.

The index of relative density of tracks in a given habitat $(A)$ for each species of mamal was calculated separately by means of the equation: $A=n t / L$, where: $n t-$ total number of tracks intersecting the observation route in a given habitat, $L-$ total length of observation route in a given habitat in $\mathrm{km}$.

When comparing the penetration of animals in different habitats, use was made of the values in percentages for degree of penetration for each species separately, taking for each of them the maximum value of index $A$ (Fig. 3) as a basis for calculations $(100 \%)$.

\section{RESULTS}

Over the whole area of the glacial valley of the Biebrza river the presence of 13 species of mamals was established (Table 1). Tracks most frequently recorded were those of the hare Lepus europaeus Pallas, 1758 - on an average $A=3.13$-i.e. one track per about $300 \mathrm{~m}$ of observation route. The second species in order of frequency of encounter was the roe deer - Capreolus capreolus (Linnaeus, 1758) with an index of 2.26 (that is, 1 track per about $400 \mathrm{~m}$ of observation route), then in turn the red fox - Vulpes vulpes (Linnaeus, 1758) - A=2.16 and the moose Alces alces (Linnaeus, 1758) with an index of 2.01. In the last two cases 1 track occurred per $0.5 \mathrm{~km}$ of route. Among more frequently encountered species was also the stoat - Mustela erminea Linnaeus, 1758 , with an index $A=1.26$ (i.e. 1 track per $800 \mathrm{~m}$ of route). Other species - the weasel - Mustela nivalis Linnaeus, 1766, the common polecat - Mustela putorius Linnaeus, 1758 , the pine marten - Martes martes (Linnaeus, 1758), raccoon dog - Nyctereutes procyonoides (Gray, 1834), the wolf Canis lupus Linnaeus, 1758, the red squirrel - Sciurus vulgaris Linnaeus, 1758, the wild boar - Sus scrofa Linnaeus, 1758 and the red deer - Cervus elaphus Linnaeus, 1758, penetrate the Biebrza valley to a far lesser extent $(A=0.31-0.02)$.

In addition to these 13 species of mammals, the beaver - Castor fiber Linnaeus, 1758 and otter - Lutra lutra (Linnaeus, 1758) were also found to occur. The presence of some less well documented species in respect of distribution in Poland (stoat, weasel, polecat, pine marten, raccoon dog, otter and beaver), determined on the strength of tracks, traces of feeding and visible traces of other activity, was taken as suf- 
ficiently proved by these criteria to warrant recording their stations. They added to the zoogeographical site data from the Biebrza valley which are given on maps of the species mentioned in the UTM grid (Pucek \& Raczyński, 1983).

\subsection{Penetration by Mammals in the Valley}

Recording tracks of the different species of mammals makes it possible to study their distribution in the various habitats of the valley. In addition, the use of the penetration index made it possible to compare the intensity of their movements within the types of habitats described (Fig. 3).

Tracks of stoats were encountered in almost all biotopes. The main habitats in which it lives are bog willow-birch shrubs and tree stands both on peat beds and hummocks, and among alder woods, clearings and young plantations within continous forest stands (chiefly in bog biotopes). Their tracks indicats the extent of the territory and methods of locating prey either on the surface of the snow or in the burrows of rodents. Through information on the way in which this species moves about under winter conditions (Vershinin, 1972), it may be taken that our observations revealed types of habitat constituing the winter territory of the stoat in the Biebrza valley. This species avoids the extensive stretches of open sedge communities and also agricultural land and pine forests on mineral soils.

Tracks of weasels were far less often found in the study area. This may be due to the weasel adoptiong a mode of hunting and moving about more under snow than the stoat (Formozov, 1932; Erlinge, 1974). Winter tracking does not therefore justify a description of the biotope preferences of the weasel. Traces of weasels are more often found in open and overgrown sedge communities than in forest habitats.

Very few tracks of the common polecat were found in the study area. This species has a large number of suitable habitats in the Biebrza valley, and therefore its low numbers may be explained by considerable human pressure (trapping, digging out from burrows). Tracks of the common polecat were most often encountered in alder woods, mixed forests and shrubs growing in various parts of the area such as sedge communities, banks of streams, and hummocks.

Tracks of the pine marten were found chiefly in the forest, most often in mesotrophic bog pine forests (Vaccinio uliginosi-Pinetum, subass. salicetosum cinerae) and in alder woods and wet pine forests with rich undergrowth. In the Biebrza valley the pine marten avoids open areas, 
dense thickets, and the successive phases of tree stands, if they are situated at a distance from mature forests which form its retreat.

The otter was not assessed for frequency of occurrence, on account of the random encounter of its tracks on the ice of frozen rivers. Recording stations of the otter during winter tracking and in other periods is therefore of faunistic importance only.

The red fox is a common predator in the community of bog habitats of the valley. Its traces are concentrated in oakhornbeam forests and on hummocks, which in winter during flooding and freezing of sedge communities form the refuge of small mammals (Raczyński et al., 1983). It only penetrates the sedge communities, undergrowth and banks of rivers to a slight degree.

The raccoon dog was only sporadically encountered, which makes analysis of habitat preference impossible. It is known from literature (Heptner et al., 1967; Nowak, 1971) that the raccoon dog inhabits bog habitats and deciduous forests. Its secretive nocturnal habits and limited activity in winter, account for the fact that its numbers and ecological role in the Biebrza valley remain unknown.

The wolf at the present time has permanent retreats in the Biebrza valley near the "Czerwone Bagno" and "Grzędy" reserves. The glacial valley of the Biebrza is situated in the breeding range of this species in north-eastern Poland (Buchalczyk, in print). The concentration of tracks in the oak-hornbeam forest ( $A=0.71$, Table 1$)$ applies to the "Długi Grąd" range in the southern basin of the valley. In 1979 during a snowy winter wolves hunted there for weak roe deer and left numerous tracks round fresh prey and carrion. Other traces were found on the paths along which wolves had passed in both open areas and wooded land in different parts of the valley. Original data on movements and hunting of wolves in the middle and lower basin of the Biebrza have been given by Trokowicz (1980).

The red squirrel, although leading principally an arboreal way of life, leaves a sufficient number of tracks in snow to make it possible both quantitatively and qualitatively to establish its presence. In the group of valley habitats the greatest density of tracks was recorded in pine forests $(A=0.78)$, and a slightly fewer number in bog pine forests $(A=0.66)$. Probably the squirrel finds more food there in winter in the form of pine and spruce seeds than in habitats with a predominance of deciduous trees. It does not enter swampy areas, and consequently birch stands and hummock with tree stands are far less frequently visited and its tracks are only sporadically found in alder woods.

The European hare penetrates into swampy areas and traces of this species are found open sedge communities. Maximum frequency of traces 
connected with feeding are, however, found in clearings and young plantations $(A=15.43)$ and in pine plantations $>10$ years old $(A=6.70)$. It was less often encountered in reed beds and although alder woods. It only sporadically visits enclaves of habitats suitable which are situated in extensive open sedge communities.

The wild boar finds retreats in the Biebrza valley in the extensive forest areas and pine plantations $>10$ years old on mineral soils. Considerable frequency of tracks occurred in the mesotrophic complexes of bog pine forests in the upper basin of the Biebrza valley ("Skieblewo Bog") and in mixed forests in different parts of the valley (Fig. 3). Additional observations show that in winter wild boar readily feed in bog forest complexes and on hummocks with a large proportion of fruiting oaks.

The distribution of the roe deer in the glacial Biebrza valley is determined by the stretches of wooded land on the boundaries of the valley and the mosaic of tree stands and bushes in swampy areas. The roe deer can thus be considered an inhabitant of wet habitats, although its density in this part of the area may be greatly reduced during exceptionally snowy winters. Within the study period this situation took place in February 1979. Traces of roe deer feeding were most often found in deciduous forests, conifer forests and in birch bushes, and also in clearings where there was a greater supply of browse. With a thin snow cover roe deer feed in herds in open sedge communities, where they are able to dig through the snow to reach herb plants and grasses. During this time they make use of slight elevations and even scanty undergrowth as places for resting and lying down while ruminating.

Tracking shows that the red deer avoids bog habitats in the Biebrza valley, and this has been confirmed by information obtained from the local forestry service. It is encountered only in the upper basin of the Biebrza adjoining the Augustów Forest. Tracks of red deer were found in mixed forests and in bog pine forests. Neither retreats of red deer nor tracks of individuals passing through were found in the dense stretch of conifer forests extending along the belt of dunes from Osowiec to Kolonia Nowa Wieś in the lower basin of the Biebrza.

The moose is a typical representative of ungulates in the bog landscape of the Biebrza. Moose tracks were most often encountered in bog willow-birch shrubs and tree stands, in pine forests with rich undergrowth and in clearings and young pine plantations. These results agree with the winter distribution of moose in the swampy part of the valley determined by means of aerial observations (Gębczyńska \& Raczyński, 1983a). 


\begin{tabular}{|c|c|c|c|c|c|c|c|}
\hline \multirow{2}{*}{ Habitats } & \multirow{2}{*}{$\begin{array}{l}\text { No. of } \\
\text { species }\end{array}$} & \multicolumn{6}{|c|}{ Species with $A>30 \%$} \\
\hline & & \begin{tabular}{|l|l|}
1 & 2 \\
\end{tabular} & 3 & 4 & 5 & 6 & 7 \\
\hline $\begin{array}{l}\text { Bog pine forests - typical } \\
\text { and mesotrophic }\end{array}$ & 10 & & & & & & \\
\hline $\begin{array}{l}\text { Bog willow - birch shrubs and } \\
\text { stands }\end{array}$ & 7 & & & & & & \\
\hline $\begin{array}{l}\text { Pine forests with rich } \\
\text { undergrowth }\end{array}$ & 7 & & & & & & \\
\hline Bog alder and birch forests & 11 & & & & & & \\
\hline Ouk - hornbeam forests & 7 & & & & & & \\
\hline $\begin{array}{l}\text { Clear-cuts and pine } \\
\text { plantations }<10 \text { years cla }\end{array}$ & 5 & & & & & & \\
\hline $\begin{array}{l}\text { Dry pine forests including } \\
\text { plantations }>10 \text { years old }\end{array}$ & 11 & & & & & & \\
\hline Mixed forests & 10 & & & & & & \\
\hline $\begin{array}{l}\text { Hummocks with shrubs and } \\
\text { tree stands }\end{array}$ & 9 & & & & & & \\
\hline $\begin{array}{l}\text { Banks of the rivers and } \\
\text { streams }\end{array}$ & 7 & & & & & & \\
\hline Dense willow thickets & 9 & & & & & & \\
\hline Meadow parts of hummocks & 3 & & & & & & \\
\hline $\begin{array}{l}\text { Sedge communities with } \\
\text { shrubs }<10 \text { years old }\end{array}$ & 10 & & & & & & \\
\hline Meodows and fields & 8 & & & & & & \\
\hline Open sedge communities & 9 & & & & & & \\
\hline $\begin{array}{l}\text { Boundary zones between alder } \\
\text { forests and sedge communities }\end{array}$ & 4 & & & & & & \\
\hline
\end{tabular}

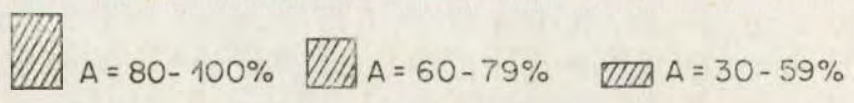

Fig. 4. Degree of use of habitats by mammals.

Intensity of penetration by different species. Maximum values of penetration index from Table 1 were taken as $100 \%$. Index values $0-29 \%$ were omitted.

\subsection{Habitat Differences of Penetration}

Classification of the 16 habitats distinguished was made on the basis of density of tracks (Fig. 4). Habitats most intensively penetrated include: bog pine forests, bog willow-birch shrubs and tree stands and pine 
forests, with rich undergrowth. It must be emphasised that the leading position of bog pine forests is due to the fact that this group is represented chiefly by the mesotrophic variant of bog pine forests. These are habitats in the successive phase of tree stands, readily used by ungulates (wild boar, moose, roe deer, red deer) and penetrated by predators (pine marten, red fox, stoat and others). Typical bog pine forests are not sufficiently represented in this class since their main complex - "Czerwone Bagno" was omitted from tracking. In the distribution of habitats examined, the mesotrophic bog pine forests were situated in the neighbourhood of the Augustow Forest, which undoubtedly had a modifying effect on the species composition of mammal community (presence of red deer, intensity of penetration by predators).

Bog willow-birch shrubs form the successive phase of birch and alder tree stands and exhibit some characteristics of forest habitats - i.e. appearance of forest species of rodents (Raczyński et al., 1983). The greatest number of tracks of roe deer, moose and stoat were found there (cf. Fig. 3).

Pine forests with rich undergrowth grow on mineral soils and are richer biotopes than dry pine forests. They form the main winter retreats of moose and roe deer. They are penetrated by 7 species of larger mammals, of which the most common are the moose, roe deer and pine marten. In respect of proportion in the observations routs these were only small sections of the area (total $6 \mathrm{~km}$ ).

The following forest habitats form a separate group of biotopes: bog alder forests (Carici-elongatae-Alnetum) and bog birch forests (Betuletum pubescentis verrucosae), oak-hornbeam forests, clearings and pine plantations, mixed forests and pine forests of different age classes.

Bog alder forests and bog birch forests, which were more numerous on the observation routs, on account of their zonal distribution, constitute places through which the numerous paths of animals lead, as they penetrate from the margin to the open valley. This explains the large number of species $(n=11)$ encountered there (Fig. 4). Penetration shows that alder forests form a permanent and preferred habitat for such predators as: common polecat, pine marten and stoat, while herbivores make only small use of bog alder forests vegetation in winter.

Oak-hornbeam forests, al'though only forming small enclaves among bogs, are an important place from the ecological aspect in which animals feed. The relatively rich food supply, in the form of browse, constitutes a common characteristic of oak-hornbeam forests and clearings and plantations in pine forests. The later, however, exhibit greater intensity of penetration by roe deer, moose and hares (cf. Tab. 1). Oak-hornbeam forests in the valley also attract predators (stoats, red foxes) hunting 
for small rodents. The intensity of penetration by the wolf is undoubtedly due to the density of ungulates (roe deer) in these habitats.

Hummocks with shrubs and tree stands - together with dense alder undergrowth - represent the next group of habitats exhibiting considerable similarity to oak-hornbeam forests, both the physionomic aspect and in results of analysis of penetration. Proof of the use made of such stands as a winter food supply by ungulates are the deformed, dwarf forms of oaks, limes and shrub species, on which roe deer browse every year and from which moose strip the bark. Dense willow thickets occur in patches in open sedge communities and form belts along ditches, streams and river beds (Table 1, habitat no. 3 and 16). Patches of undergrowth are penetrated chiefly by predatory mammals, but are also browsed on by hares and to a lesser degree by ungulates.

Rivers would appear to play a different ecological role. These are primarily the penetration paths of predators searching for prey in the rushy zone and on elevations (often not flooded) of the banks of the rivers Biebrza and Ełk and the Woznawiejski Canal. The banks of rivers and streams form the typical habitat of the weasel and places of penetration by the common polecat, stoat and red fox. Streams remaining free of ice are inhabitated by the otter, which finds favourable living conditions there (the natural character of the river, numerous old water courses, meanders and rush biotopes with an abundance of fish). The otter population in the valley, however, is subject to the limiting influence of man, as the result of specialized poaching.

The sedge communities and the cultivated areas situated on the margin of the valley are penetrated by mammals to a minimum degree only (Fig. 4). As the extensive open sedge communities become colonised by bushes, they are penetrated more by carnivores.

Figure 5 illustrates the degree to which predatory mammals and deer make use of the given habitats of the valley. The community of predatory mammals of the valley chiefly penetrates the typical bog alder forests and bog birch forests, oak-hornbeam forests and bog pine forests, bog willow-birch shrubs, the banks of rivers and streams. Among least preferred habitats are the open sedge communities, cultivated fields and the boundary zones between alder beds and sedge communities. This last habitat in fact forms a poorly representative sample, on account of the relatively short length of the observation route.

Penetration of the given area by predators is usually the result of their activity in searching for prey. Larger predatory mammals wolves or red foxes, having a large penetration range, cover a large number of habitats in their territory, which are often situated at considerable distances from each other. The most frequently used routes 


\begin{tabular}{|c|c|c|c|c|}
\hline \multirow{2}{*}{ Habitats } & \multicolumn{4}{|c|}{$\begin{array}{l}\text { No. of species } \\
\text { CARNIVORA } \\
\end{array}$} \\
\hline & Total & with $A>30 \%$ & $\begin{array}{c}\text { with } A>30 \% \\
1\end{array}$ & Total \\
\hline Bog alder and birch forests & 6 & DIDI & DIn & 3 \\
\hline Oak-hornbeam forests & 4 & DIDIII & $D$ & 2 \\
\hline $\begin{array}{l}\text { Banks of the rivers and } \\
\text { streams }\end{array}$ & 4 & & & 2 \\
\hline $\begin{array}{l}\text { Bog pine forests-typical } \\
\text { and mesotrophic }\end{array}$ & 4 & & $D$ & 3 \\
\hline Dense willow thickets & 6 & & & $\hat{2}$ \\
\hline Meadow parts of hummocks & 2 & & & 1 \\
\hline $\begin{array}{l}\text { Hummocks with shrubs and } \\
\text { tree stands }\end{array}$ & 5 & पIIXIII & WIIIA & 2 \\
\hline $\begin{array}{l}\text { Clear-cuts and pine } \\
\text { plantations }<10 \text { years old }\end{array}$ & 2 & VIII & & 2 \\
\hline $\begin{array}{l}\text { Bog willow-birch shrubs } \\
\text { and stands }\end{array}$ & 3 & & DIA & 2 \\
\hline Mixed forests & 5 & & VIA & 3 \\
\hline $\begin{array}{l}\text { Sedge communities with } \\
\text { shrubs }<10 \text { years old }\end{array}$ & 6 & & & 2 \\
\hline $\begin{array}{l}\text { Pine forests with rich } \\
\text { undergrowth }\end{array}$ & 3 & & DIDA & 2 \\
\hline $\begin{array}{l}\text { Dry pine forests including } \\
\text { plantations }>10 \text { years old }\end{array}$ & 5 & & WIIT & 3 \\
\hline Open sedge communities & 6 & & & 2 \\
\hline $\begin{array}{l}\text { Boundary zones between alder } \\
\text { forests and sedge communities }\end{array}$ & 1 & & & 2 \\
\hline Meadows and fields & 3 & & & 3 \\
\hline
\end{tabular}

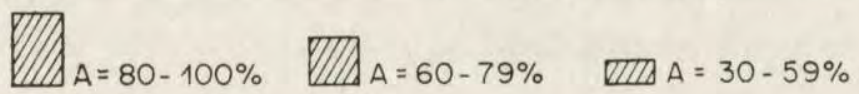

Fig. 5. Degree of use of habitats by Carnivora and Cervidae.

Intensity of penetration by different species. Maximum values of penetration index from Table 1 were taken as $100 \%$. Index values $0-29 \%$ were omitted.

are the banks of rivers and streams, which is not fully reflected in the number of tracks, on account of the plan of observation routes used for these studies. Wolves often use both roads and paths (Trokowicz, 1980). Smaller predators, e.g. the common polecat, and stoat, make smaller movement and betray by their tracks the location of their winter territories. 
The ungulate mammals are represented by deer. They prefer bog willow-birch shrubs and tree stands and pine forests with rich undergrowth. The other habitats, such as mixed forests, bog pine forests and dry pine forests, together with clearings and plantations and al'so oakhornbeam forests - were penetrated to a much lesser degree. The movements of ungulates are determined chiefly by feeding requirements, the result of which is greater density of tracks in habits with abundant and easily accessible browse, which is preferred by these animals. Bog willow-birch shrubs and successive birch undergrowth meet these conditions, particularly in the middle basin, and are intensively used by moose. These habitats are characterized by high penetration indices, like coniferous forests (Table 1). It must, however, be borne in mind that these two types of habitat are not identically represented in the present studies.

\section{DISCUSSION}

Even when tracks are counted in the same area, comparison of penetration indices for different animals is not valid on account of the way in which different species move about. In our studies indices were calculated individually for each species in different habitats (cf. section 3). Comparisons in the habitats were made taking into consideration the degree of variation of the penetration index specific to the species. For instance, small predators - the weasel and stoat, are highly specialized in their food requirements and prey on small mammals, chiefly voles (Pulliainen, 1981). This specialization determines their distribution in the valley on higher ground in peat beds, which are occupied by rodents when the water l'evel rises. Larger predators such the red fox, with a wider food spectrum, are not so closely connected with particular habitats, which is shown by the considerable dispersion of peneration (Fig. 3 ). At the same time, however, winter observations shown that most of the red fox earths are situated on the dry hummocks in the bog.

Winter penetration of the area by large ungulate mammals is differently conditioned. In winter they form herds wandering in search of food. Their potentially greater mobility cause ungulates to pass through habitats which are not suitable, but which lie on the route of their movements. The probability of such a situation increases with the zonal distribution of habitats in the valley. It would appear that the places of winter distribution of deer are mainly connected with the possibility of feeding. In the valley it is possible to discount the effect of supplementary winter feeding and disturbance due to human activity.

Fuller \& Robinson (1982) have drawn attention to differences in 
habitat selection between predators and deer under winter conditions.

A factor causing differences in the winter movements of ungulates is the depth of the snow cover. According to Cederlund et al. (1980), the mobility of roe deer and moose is limited by snow deep enough to reach chest height of the animals (respectively 50 and $105 \mathrm{~cm}$ ). Variations in the animal's' diet are revealed with depths of snow cover far below the critical value for the species. During the period of our studies it was only during the winter season 1978/1979 that the snow cover exceeded critical values for roe deer, reaching a depth in February of about $80-100 \mathrm{~cm}$. According to Vereščagin \& Rusakov (1979) snow cover $30 \mathrm{~cm}$ deep is enough to cause serious disturbance in the composition of the roe deer's diet and causes exhaustion. Extremely weak roe deer were encountered during the winter of $1978 / 1979$ on hummocks, and tracks in the snow pointed to their limited locomotor activity and failure to obtain food from beneath the snow. During this period no traces of moose were found in the lower basin of the Biebrza in the swampy part of the valley. These facts were confirmed by later observations from the air, when it was found that intensity of the moose's migration from bogs to young pine plantations on the mineral bank of the valley were conditioned, inter alia, by the depth of the snow cover (Gębczyńska \& Raczyński, 1983a).

The type and intensity of winter penetration of the Biebrza valley by different species of mammals is a process with both general and specific conditioning. Among general factors we may include the population density of the given species, particularly in cases when this is subject to considerable fluctuation. For instance, data obtained by us on habitat selection of the hare in the valley relate to the period of depression in the numbers of this species over the whole region of north- eastern Poland (Raczyński, unpubl.).

The specific ecological conditions of the valley are also responsible for the distribution of the winter penetration of mammals. The upper basin of the Biebrza is strongly influenced by the Augustów Forest, an extensive area of wooded land with suitable habitat for both red deer and moose. The red deer's penetration of the valley is limited to its margin in the area of the upper basin and includes the biotope of mesotrophic bog pine forests. These complexes are in contact with the Augustów Forest through other wooded areas. It was found that red deer do not go far into peat beds and do not use the valley as a migration route to suitable forest habitats, situated in other parts of the Biebrza valley. It may in addition be a case here of red deer avoiding bog habitats and competition between moose and red deer in a forest habitat. The results of such influences in the Białowieża Primeval' Forest. 
have been described by Wróblewski (1927). Interchange of the Biebrza population of moose and these living in the Augustow Forest have not so far been examined. The pattern of seasonal migration of moose found in different parts of the valley (Gębczyńska \& Raczyński, 1983a), suggest the possibility of interchange of individuals or even the existence of a common population.

The seasonal migration of moose in the valley apply to two types of habitats: peat beds where the animals remain during the growing season and young pine plantations on mineral soils, which are occupied in winter. Habitat selection of moose in the valley has been described in detail by Gębczyńska \& Raczyński (1983a, b). The fact must be emphasized that movements in the two parts of the valley at no great distance from each other - the lower and middle basins - differ considerably in pattern and intensity. A larger number of moose in the middle basin remain in bogs in the winter and feed on bog willow-birch shrubs. Although the vegetation and bog habitats of the lower and middle basin are similar, there is a different pattern of winter movement, and the majority of the local population migrates to nearby pine forests (Gębczyńska \& Raczyński, 1983a). It would appear that the decisive factor in its migrations is the amount of the natural food and its availability during the winter. The spatial distribution of habitats richer in winter food may determine the direction and range of these migrations. In this sense the habitat preference of large ungulates may be modified by the specific ecological structure of the whole area.

Acknowledgements: Messrs S. Buszko and J. Siemieniuk took part, together with the authors, in the field studies, and we wish to express our grateful thanks to them.

\section{REFERENCES}

1. Buchalczyk T. (in print): Zmiany w zasięgu wilka (mapa). [In: "Atlas zasobów, walorów i zagrożeń środowiska geograficznego Polski”, Ed. S. Leszczycki].

2. Cederlund G., Ljungqvist H., Markgren G. \& Stälfelt F., 1980: Foods of moose and roe-deer at Grimsö in central Sweden - results of rumen content analyses. Viltrevy, 11: $1-247$.

3. Dzięciołowski R., 1976: Estimating ungulate numbers in a forest by track counts. Acta theriol., 21: 217-222.

4. Erlinge S., 1974: Distribution, territoriality and numbers of the weasel Mustela nivalis in relation to prey abundance. Oikos, 25: 308-314.

5. Erlinge S., 1977: Home range utilization and movements of the stoat Mustela erminea. [In: XIIIth International Congress of Game Biologists, Atlanta, Georgia USA]: $31-42$. Washington.

46. Formozov A. N., 1932: Formula dla količestvennogo učeta mlekopitajuščich po sledam. Zool. Ž., 11: $66-69$. 
7. Fuller T. K. \& Robinson W. L., 1982: Winter movements of mammals across a large northern river. J. Mamm., 63: 506-510.

8. Gębczyńska Z. \& Raczyński J., 1983a: Habitat preference and population structure of moose in the Biebrza river valley. Acta zool. Fennica (in print).

9. Gębczyńska Z. \& Raczyński J., 1983b: Ispolzovanie ugodij losjami v raznych biotopach doliny reki Biebrzy. [In: XVIth Congress of Game Biol. Ed. M. Spenik] (in print).

10. Goszczyński J., 1981: Use of carthographic method in studies of area penetration by mammals. Wiad, ekol., 27: 253-262. [In Polish with English summ.].

11. Heptner V. G., Naumov N. P., Jurgenson P. B., Sludskij A. A., Cirkova A. F. \& Bannikov A. G. 1967: Mlekopitajušcije Sovetskogo Sojuza. Izd. Vysšaja Skola, 2: 1-1004. Moskva.

12. Krzywonos K., 1965: Warunki klimatyczne rejonu rolniczego Zakładu Badawczego Biebrza w latach 1954-1963. [In: "Wyniki doświadczeń Rolniczego Zakładu Badawczego Biebrza 1954-1963", Biblioteczka "Wiadomości IMUZ", 17: 188-221.

13. Kuzjakin V. A., 1979: Ochotnie'ja taksacija. Izd. Lesnaja promyšlennost': 1-200. Moskva.

14. Mech L. D., 1966: The wolves of Isle Royale. Fauna of the National Parks of the United States. Fauna series, 7: 1-210.

15. Nasimovi ̌ A. A., 1963: Osnovnyje napravlenija v razrabotkie metodov koliðestvennogo učeta dikich kopytnych. [In: "Resursy fauny promyslovych zverej v SSSR i ich učet". Eds. I. A. Isakov, A. A. Nasimovix]. Izd. AN SSSR; 64-83. Moskva.

16. Nowak E., 1971: The range expansion of animals and its causes. Zesz, nauk, Inst. Ekol, PAN, 3: 3-225 [In Polish with English summ.].

17. Okruszko H., 1973: The Biebrza river valley characteristics under natural and agricultural point of view. Zesz. probl. Post. Nauk roln., 134: 173-199.

18. Oświt J., 1973: Warunki rozwoju torfowisk w dolinie dolnej Biebrzy na tle stosunkbw wodnych. Roczn. Nauk roln., ser. D - Monografie, 143: 1-80.

19. Oświt J. \& Zurek S., 1981: Rekonstrukcja rozwoju zabagnień w pradolínie Biebrzy. Zesz. nauk. Akad, roln. Wrocław, 134. Roln., 38: 59-69.

20. Pałczyński A., 1975: Bagna Jaćwieskie (Pradolina Biebrzy). Roczn. Nauk roln. ser. D - Monografie, 145: 1-232.

21. Pałczyński A., 1981: Zmiany sukcesyjne roślinności jako wskaźnik eutrofizacji torfowisk w dolinie Biebrzy. Zesz, nauk. Akad, roln., Wrocław, 131, Roln., 36: 15-19.

22. Pucek Z. \& Raczyński J. (Eds) 1983: Atlas of Polish mammals. Państw. Wyd. Nauk.: $1-188+1-183$. Warszawa.

23. Pulliainen E., 1981: A transect survey of small land carnivore and red fox populations on a subartic fell in Finnish Forest Lapland over 13 winters. Ann. Zool. Fennici, 18: 270-278.

24. Raczyński J., Fedyk S., Gębczyńska Z. \& Pucek M., 1983: Small mammals in the middle and lower basin of the Biebrza river valley. Zesz. probl. Post. Nauk roln., 255: 297-328 [In Polish with English summ.].

25. Raczyński J., Fedyk S., Gębczyńska Z. \& Pucek M., 1984: Rozmieszczenie drobnych ssaków na tle naturalnego zróżnicowania środowisk pradoliny Biebrzy. Pol, ecol. Studies (in print).

26. Trokowicz L., 1980: Tropienie wilków w dolinie Biebrzy. Prz. zool., 14: 137-145. 
27. Verešçagin N. K. \& Rusakov O. S., 1970: Kopytnyje Severo-Zapada SSSR. Nauka: $1-308$. Leningrad.

28. Vershinin A. A., 1972: Biologija i promysel' Kamčatskogo gornostaja. Bjul. Mosk. O-va Isp. Prirody. Biol., 77: 16-26.

29. Wróblewski K., 1927: Zubr Puszczy Białowieskiej. Wyd. Polskie: 1-232. Poznań.

Accepted, June 18, 1984.

Stanisław FEDYK, Zofia GËBCZYNSSKA, Michalina PUCEK, Jan RACZYÑSKI i Michał D. SIKORSKI

\author{
ZIMOWA PENETRACJA SSAKOW \\ W SRODOWISKACH DOLINY BIEBRZY
}

\title{
Streszczenie
}

Liczenie tropów ssakb́w drapieżnych, kopytnych, gryzoni i zajęcy (lącznie 13 gatunków) prowadzono w ciągu 4 kolejnych zim 1977-1980, na marszrutach o łącznej długości $383 \mathrm{~km}$, przebiegających przez zespbł środowisk gornego, środkowego i dolnego basenu Biebrzy (Ryc. 1 A, B, Ryc. 2). W oparciu o wyliczony wskaźnik penetracji $A$ (Tabela 1, Ryc. 3) stwierdzono, że zespol ssaków drapieżnych (wilk, lis, jenot, kuna, tchorz, gronostaj i lasica) penetruje najintensywniej olsy typowe i brzozowe, lasy grądowe i bory bagienne w odmianie łozowej, zwarte zarośla lozowo-brzozowe oraz brzegi rzek i cieków wodnych. Tropy jeleniowatych (los, sarna, jeleń) spotykano najczęściej w zadrzewieniach i zakrzaczeniach łozowobrzozowych $\mathrm{i}$ borach świeżych oraz w mniejszym stopniu w innych typach lasów (Ryc. 5). Największe zagęszczenie tropow ogólu rejestrowanych gatunkow stwierdzono $w$ mezotroficznych borach bagiennych w gornym basenie Biebrzy, sukcesyjnych zaroślach łozowo-brzozowych oraz w borach swieżych i olsach typowych i brzozowych. Otwarte turzycowiska, z wyjątkiem położonych na nich grądzików, są najmniej penetrowanymi środowiskami doliny (Ryc. 4). Stwierdzono, że zimowa ruchliwośc drapieżników związana jest z poszukiwaniem zdobyczy, zaś preferencje środowiskowe jeleniowatych określa zapas i dostępność żeru zimowego. Łosie wykazują zróżnicowane preferencje środowiskowe w obrębie areału w dolinie, uwarunkowane układem przestrzennym (sąsiedztwem) zasobnych $\mathrm{w}$ żer pędowy ostoi zimowych. Lokalne układy środowiskowe $w$ dolnym basenie sprzyjają zimowej migracji losi $\mathrm{z}$ terenów bagiennych do kultur sosnowych na terenach mineralnych. Obserwacje terenowe pozwoliły uzupełnic dane do rozmieszczenia $w$ dolinie Biebrzy paru rzadszych gatunków ssaków. 